\title{
BEHAVIOURAL RESPONSE OF NORTHERN BASKET STAR GORGONOCEPHALUS ARCTICUS TO MECHANICAL STIMULATIONS
}

\author{
J.-F. HAMEL and A. MERCIER \\ Département d'océanographie, Université du Québec à Rimouski, \\ Centre Océanographique de Rimouski, 310 allée des Ursulines, Rimouski (Québec), Canada G5L 3AI
}

GORGONOCEPHALUS OPHIURE COMPORTEMENT MECANO-SENSIBILITE

GORGONOCEPHALUS OPHIUROID BRITTLESTAR BEHAVIOUR MECHANOSENSITIVITY

\section{INTRODUCTION}

Ophiuroids, like most echinoderms, are known to react when stimulated by water-borne chemicals (Moore and Cobb, 1985b; May, 1925), changing lighting (Cowles, 1910 ; May, 1925; Moore and Cobb, 1985a ; Tsurnamal and Marder, 1966), currents and vibrations (Moore and Cobb,
RÉSUME - L'Ophiure ramifiée Gorgonocephalus arcticus, retrouvée dans les eaux profondes de l'estuaire du Saint-Laurent, montre une capacité de discrimination tactile qui lui permet de répondre proportionnellement à diverses intensités de stimulation. Une stimulation ponctuelle du disque provoque l'enroulement général des bras et la couverture du disque par les radii. Une comparaison de la vitesse du mouvement des bras, induite par différents niveaux de stimulation, montre que G. arcticus réagit significativement plus rapidement et plus intensément à une forte pression qu'à une pression légère ou d'intensité intermédiaire. Une pression sur un bras ne génère pas de réaction globale, mais plutôt un lent mouvement à proximité des ramifications stimulées. Dans le cas de stimulations simultanées sur deux sites distincts, la couverture du disque se produit uniquement lorsque celles-ci sont administrées dans la zone interambulacraire. Cependant, lorsque les deux stimulations simultanées affectent des bras adjacents, le même bras ou un bras et le disque, aucune réaction n'est observée, tandis qu'une discrète activité devient perceptible suite à la stimulation successive de deux bras adjacents. Cette étude présente les premières observations comportementales de mécano-sensibilité réalisées chez une Ophiure ramifiée. Ces Ophiuroïdes semblent développer des réactions plus complexes que celles observées chez les Ophiures non ramifiées, ce qui suggère un niveau d'organisation différent du système nerveux.

ABSTRACT - Gorgonocephalus arcticus, a basket star from the deep St. Lawrence Estuary shows intensity and tactile discriminatory abilities. The pinpoint mechanical stimulation of the disk induces a succession of reactions involving general arm coiling and covering of the disk by radii. The statistical comparison between temporal development of arm movements provoked by different intensities of stimuli demonstrates that $G$. arcticus reacts faster and stronger to a strong pressure than to a light or intermediate one. A pressure inflicted to an arm does not generate a global reaction but a localized and slow movement of the surrounding branches. In the case of a simultaneous double-site stimulation, a complete reaction, including covering of the disk, occurs only when both stimulations are inflicted to the radial shield. When the two stimuli involve adjacent arms, the same arm or an arm and the disk, almost no reaction is observed. A discrete local activity is perceptible after successive stimulation of two adjacent arms. This study presents the first behavioural observations of mechanosensitivity made on basket stars. These ophiuroids seem to develop a more complex pattern of reactions than the one observed in unbranched brittlestars, which could suggest a different level of organization of the nervous system.
1986) or physical contact with the surrounding substrate (Cowles, 1910 ; Emson and Wilkie, 1982 ; May, 1925). These studies have demonstrated photo-repulsion, chemotaxism and mechanosensitivity, showing that the ophiuroids' nervous system seems to allow them a general detection of environmental variations concerning food availability or life threatening situations. 
In this study we examine the behavioural response of the basket star Gorgonocephalus arcticus toward different intensities of more pinpoint stimulations. Because of its large size (up to $400 \mathrm{~mm}$ in total diameter), complex ramification and flexibility, this echinoderm's responses to mechanosensitivity experiments are clearly visible. Basket stars feed on planktonic organisms (zooplankton and micronekton), trapping them with their arms extended as a fan in the water (Warner, 1982; Meyer and Lane, 1976). Being scarce along the east coast of Canada (3-5 ind $\left./ \mathrm{km}^{2}\right)$ and living at great depths (60$1500 \mathrm{~m}$; Amos and Amos, 1981) this group of echinoderms has only been the subject of a few studies concerning its morphology, reproduction, feeding habits and life cycle (Dearborn, 1977; Fedotov, 1915 ; Meyer and Lane, 1976 ; Patent, 1969, 1970a and 1970b).

However, mechanosensitivity abilities have been well studied in some unbranched ophiuroids, mostly of the genus Ophiura. The early studies (Cowles, 1910; May, 1925) took a behavioural approach to examine the sensory reactions in a broad manner. More recently, neurophysiological techniques (Moore and Cobb, 1986) and investigation of the nervous system (Cobb and Stubbs, 1981 and 1982 ; Cobb and Moore, 1986) have tried to link reactions with the morphology and distribution of neurones and receptor sites. Still, these experiments examine reactions induced by environmental changes (vibrations, currents, lighting), detected by the whole animal, which responds to it by global movement or freezing. We would like to show that a more direct short-term stimulation can induce a controlled reaction and that the behaviour of Gorgonocephalus arcticus depends on the site of impact and the intensity of the stimulus.

\section{METHODS}

To examine the sensory reaction of the basket star Gorgonocephalus arcticus, individuals were randomly collected during autumn 1992 in front of Rimouski $\left(48^{\circ} 21^{\prime} \mathrm{N}\right.$ : $\left.68^{\circ} 47^{\prime} \mathrm{W}\right)$ on the south shore of the lower St. Lawrence Estuary, eastern Canada. A total of 10 specimens, ranging from 65 to $80 \mathrm{~mm}$ in disk diameter (equivalent to $350-400$ $\mathrm{mm}$ in total diameter), were dredged from muddy bottoms at approximatively $200 \mathrm{~m}$ in depth and allowed a two-week acclimation period. Subsequently, experiments were conducted in a nalgen tank $(90 \times 60 \times 30 \mathrm{~cm})$ at $5-6{ }^{\circ} \mathrm{C}$ and a salinity around 30 , conditions provided by a flow-through system of natural seawater. These facilities were provided by the Station Aquicole de Pointeau-Père, near Rimouski. The animals were fed regularly with a mix of zooplankton and phytoplankton for the total duration of their captivity.

\section{Sensitivity related reactions}

The possibility of different types and intensities of response was assessed by using three distinct degrees of stimulation : a light pressure $(46.3 \pm$ $9.9 \mathrm{~N})$, an intermediate pressure $(227.3 \pm 30.4 \mathrm{~N})$ and a strong pressure $(426.8 \pm 47.2 \mathrm{~N})$, always on the radial shield's surface. In this experiment and the following, the stimulus was applied during $\approx 1 \mathrm{sec}$ with the needle of a syringe $(0.5 \mathrm{~mm}$ in diameter, stainless steel). Stimulations where always inflicted with care, in order to avoid water movements that could induce false responses. Glass and plastic instruments were previously tested as stimulus inducers, to make sure the reactions did not result from chemical detection. The shade produced by the experimenter and by instruments did not affect the ophiuroid's behaviour and physical contact with the needle was always necessary to induce a visible reaction.

Observations on long-term stimulus reactions were made after introduction of a small needle in the disk $(0.2 \mathrm{~mm}$ in diameter, stainless steel) for over $24 \mathrm{~h}$.

\section{Tactile discrimination abilities}

Single stimulation. In order to test the ophiuroid's ability to locate a stimulus, a strong pressure was inflicted to different body parts. Three areas of the arm were stimulated : the base, where the arm attaches to the disk, the middle portion and finally the far tip. Three areas of the disk were also studied, the aboral center and the radial shield on both oral and aboral side (Fig. 1).

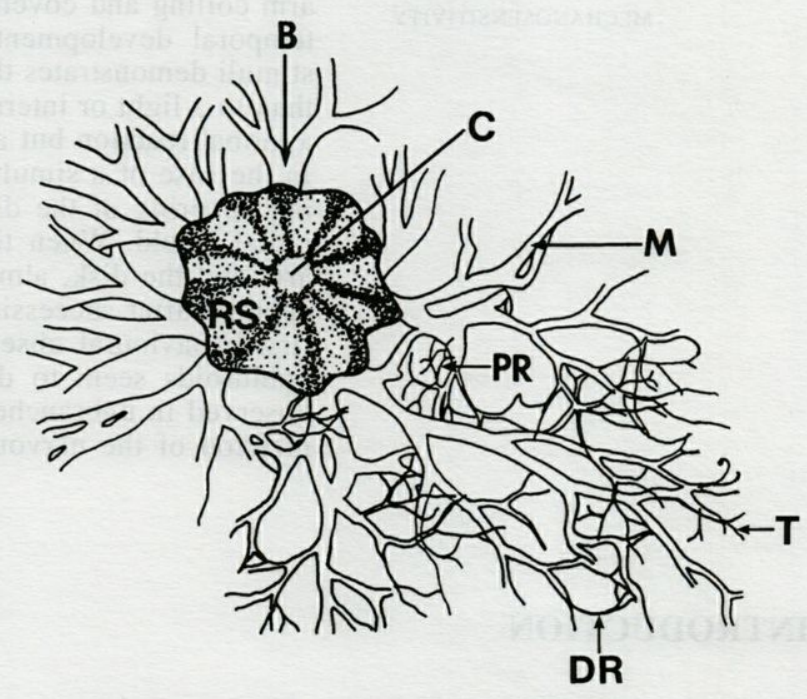

Fig. 1. - Sketch of Gorgonocephalus arcticus, aboral view, showing the different body parts and the stimulated areas. C : central portion of disk, RS : radial shield, $\mathrm{B}$ : base section of the arm, M : middle section of the arm, T : tip of the arm, PR : proximal radii, DR : distal radii. 
Double stimulation. Two strong pressures, 50 $\mathrm{mm}$ apart, were simultaneously inflicted 1 ) on the aboral radial shield and the arm (around $20 \mathrm{~mm}$ from the base of the arm), 2) at 2 sites on the dorsal face of the disk, 3) at two sites on the same arm and 4) on two different arms. One last procedure consisted of two successive strong pressures, 2-3 sec apart, applied on two different arms. Informations for those experiments were recorded from the reactions of 8 individuals.

The different arm movements, the order in which they occurred and the temporal development of the reactions were noted. The proportion of the disk covered by arms was estimated qualitatively during a reaction and corroborated by the study of photographic sequences took during the experiment.

A minimum delay of 2 hours was allowed between each experiment. Mann and Witney U statistical analysis was performed to determine significant differences between the rapidity of reaction after each level of stimulation.

\section{RESULTS}

Before the stimulation, the individuals show no apparent movements, and their arms, which are fully extended, make no contact with the central disk. A portion of them may be coiled to provide attachment to the substrate.

\section{Sensitivity related reactions}

Following the stimulation of the disk, a clear movement of most ramifications is perceptible, the smallest ones bending toward the center and the biggest ones staying on the outside (Fig. 2). The initiation of the reaction is significantly slower after a light pressure than after a stronger stimulus $(p \leqslant 0.001)$ (Table I). The small radii reach the disk first and progressively begin to cover its surface in a sweeping movement. Meanwhile, the extremities of the arms tend to rise, forming a surrounding barrier and overlaying the disk at a distance. The radii on the disk seem to slowly confirm their disposition and congregate to the stimulated area while their number increases (Fig. 2). A faster covering of the disk is attained after an intense stimulation, for example $50 \%$ of the disk is covered after an average of $111 \mathrm{sec}$ in the case of a strong pressure, an average of 154 sec for the intermediate pressure and never occurs following a light pressure (Table I). A highly significant difference $(p \leqslant 0.001)$ is observed between corresponding times of covering for all percentages except for maximum covering
$(65 \%)$ between the intermediate and the strong pressure $(p=0.643)$. At the peak of a very intense response (induced by a strong pressure), the distal portion of an arm might also reach the disk (3 times out of 7). After a time, which is longer for the strongest stimulation, the reaction's intensity decreases and the arms leave the central area. The distal branches retract first, progressively followed by the proximal radii. In other words a more intense stimulus proves to generate significally more rapid and longer lasting reactions (Table I).

The long-term stimulation generates a reaction similar to the one observed after a strong pressure but small radii have a tendency to hold on to the needle several hours after the animal's return to an extended resting position. Eventually, $>24 \mathrm{~h}$ after the stimulation, the needle is freed of any contact with the ophiuroid's arms.

\section{Tactile discrimination abilities}

Single stimulation. When only the arms are stimulated, in a soft or strong way, no covering of the disk occurs (Table II). When the arm tip is stimulated, a waving movement affects only a limited group of radii in the immediate vicinity of the stimulated area for $\approx 2 \mathrm{~min}$. A stimulus in the middle or on the base of an arm generates reactions which are similar: the ramifications of the stimulated arm bend toward the site of impact and slight activity is perceptible among the surrounding arms for $\approx 4 \mathrm{~min}$.

Stimulations on the center of the dorsal disk and on both sides of the radial shield generate a global reaction as described in the sensitivity related reactions section. The covering only occurs on the stimulated side. The site of impact on the disk is always the last to be totally freed of radii. A reaction is visible within $4-14 \mathrm{sec}$ after a stimulation on the disk and only after $30-60 \mathrm{sec}$ after stimulation in the middle or the base of an arm. Although extremely localized, the reaction after stimulation of an arm tip is almost immediate (4-5 $\mathrm{sec}$ at the most).

Double stimulation. When simultaneous stimuli are used, two types of reactions can be observed depending on the site of impact (Table II). Simultaneous stimulations, whether on the same arm, two distinct arms or on the aboral radial shield and an arm section, induce barely perceptible movements of the arm tips. However, when the two stimulations affect the dorsal side of the disk, a strong reaction develops in the pattern observed for a single stimulus on the radial shield. 

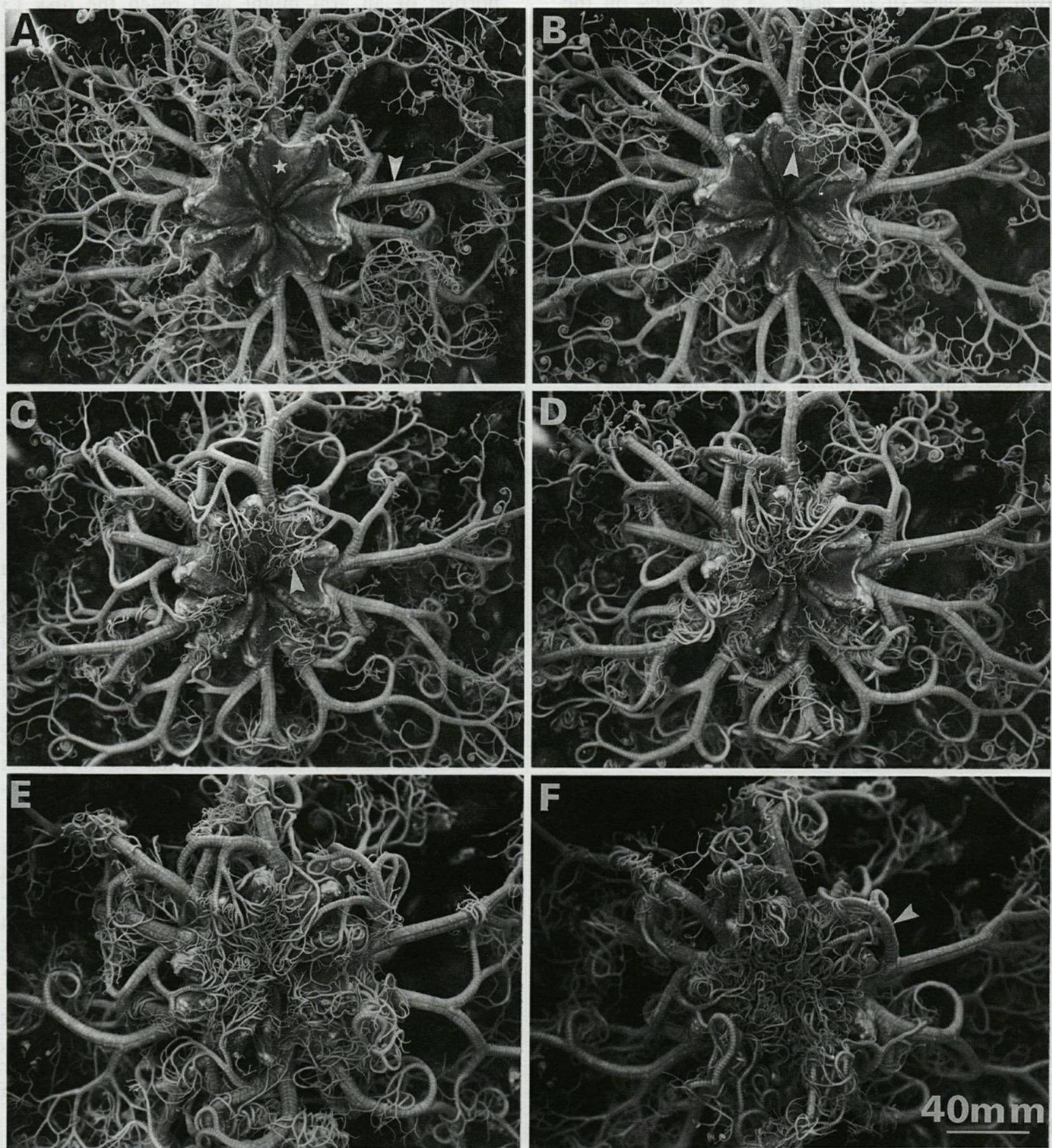

Fig. 2. - Photographs showing the reaction of Gorgonocephalus arcticus after a strong pressure on the aboral radial shield. A, Animal in resting position. The arrow shows the main branch of an arm and the asterisk indicates the stimulation site. B, First contact of proximal radii on the disk (4 sec after stimulation). The arrow points to the small radii beginning to cover the disk. C, $10 \%$ of disk covered by radii $(25 \mathrm{sec})$. The arrow again points to radii. D, and E, Progressive disk covering. F, Maximum covering of the disk (135 sec ; $65 \%)$. The arrow indicates a main arm section reaching the disk. All time values given represent an average for the 6 individuals tested. 
Table I. - Gorgonocephalus arcticus. Temporal development of the reaction in relation to the intensity of the stimulation. Values in parentheses represent the confidence intervals $(95 \%)$ and the number of individuals tested $(\mathrm{n})$ is indicated below each treatment.

\begin{tabular}{|c|c|c|c|c|c|c|c|}
\hline \multirow[t]{2}{*}{ Stimuli } & \multirow{2}{*}{$\begin{array}{l}\text { Initiation } \\
\text { of arm } \\
\text { movement } \\
\text { (sec) }\end{array}$} & \multicolumn{4}{|c|}{$\begin{array}{l}\text { Portion of the disk } \\
\text { cover by arms (sec) }\end{array}$} & \multirow{2}{*}{$\begin{array}{l}\text { Beginning } \\
\text { of arm } \\
\text { retraction } \\
\text { (sec) }\end{array}$} & \multirow{2}{*}{$\begin{array}{l}\text { Total } \\
\text { duration of } \\
\text { the reaction } \\
\text { (min) }\end{array}$} \\
\hline & & $210 \%$ & $25 \%$ & $50 \%$ & $265 \%$ & & \\
\hline Light & & & & & & & \\
\hline $\begin{array}{l}\text { pressure } \\
(\mathrm{n}=5)\end{array}$ & $\begin{array}{l}14 \\
(4.3)\end{array}$ & $\begin{array}{l}99 \\
(13.9)\end{array}$ & - & - & $\cdot$ & $\begin{array}{l}158 \\
(30.6)\end{array}$ & $\begin{array}{l}8 \\
(2.1)\end{array}$ \\
\hline $\begin{array}{l}\text { Intermedi } \\
\text { pressure } \\
(\mathrm{n}=7)\end{array}$ & $\begin{array}{c}5 \\
(2.4)\end{array}$ & $\begin{array}{l}67 \\
(2.1)\end{array}$ & $\begin{array}{c}89 \\
(42.1)\end{array}$ & $\begin{array}{l}154 \\
(31.3)\end{array}$ & $\begin{array}{l}181 \\
(26.5)\end{array}$ & $\begin{array}{l}261 \\
(44.7)\end{array}$ & $\begin{array}{c}41 \\
(13.2)\end{array}$ \\
\hline $\begin{array}{l}\text { Strong } \\
\text { pressure } \\
(n=6)\end{array}$ & $\begin{array}{c}4 \\
(1.3)\end{array}$ & $\begin{array}{l}25 \\
(6.3)\end{array}$ & $\begin{array}{l}52 \\
(9.8)\end{array}$ & $\begin{array}{l}111 \\
(20.1)\end{array}$ & $\begin{array}{l}135 \\
(12.3)\end{array}$ & $\begin{array}{l}314 \\
(112.4)\end{array}$ & 260 \\
\hline
\end{tabular}

Table II. - Gorgonocephalus arcticus. Summary of reactions induced by a strong pressure on different body parts.

\begin{tabular}{lllll}
\hline \multicolumn{3}{c}{ Description of the reaction } \\
$\begin{array}{l}\text { General } \\
\text { movement } \\
\text { of all arms }\end{array}$ & $\begin{array}{l}\text { Covering } \\
\text { of the } \\
\text { disk }\end{array}$ & $\begin{array}{l}\text { Arm coilling } \\
\text { site }\end{array}$ & $\begin{array}{l}\text { Local } \\
\text { movement } \\
\text { around } \\
\text { stimulated } \\
\text { area }\end{array}$ & $\begin{array}{l}\text { Almost } \\
\text { no } \\
\text { reaction }\end{array}$ \\
\hline
\end{tabular}

\begin{tabular}{|c|c|c|c|c|c|}
\hline \multicolumn{6}{|l|}{ Single stimulation } \\
\hline Base of the arm & & & $\mathrm{x}$ & $x$ & \\
\hline Middle of the arm & & & $\mathrm{x}$ & $x$ & \\
\hline Tip of the arm & & & & $x$ & \\
\hline Center of disk (aboral) & $\mathrm{x}$ & $\mathrm{x}$ & $x$ & & \\
\hline Radial shield (aboral) & $x$ & $x$ & $x$ & & \\
\hline Radial shield (oral) & $x$ & $x$ & $x$ & & \\
\hline \multicolumn{6}{|l|}{$\begin{array}{l}\text { Double stimulation } \\
\text { (simultaneous) }\end{array}$} \\
\hline $\begin{array}{l}\text { Both on aboral } \\
\text { radial shield }\end{array}$ & $x$ & $x$ & $x$ & & \\
\hline $\begin{array}{l}\text { Arm-aboral radial } \\
\text { shield }\end{array}$ & & & & & $\mathrm{x}$ \\
\hline Both on same arm & & & & & $x$ \\
\hline On two adjacent arms & & & & & $\mathrm{x}$ \\
\hline \multicolumn{6}{|l|}{$\begin{array}{l}\text { Double stimulation } \\
\text { (successively) }\end{array}$} \\
\hline Two adjacent arms & & & & $x$ & \\
\hline
\end{tabular}

When two successive stimuli are applied to adjacent branches, movements of the arms are evident but still restricted to the stimulated area.

\section{DISCUSSION}

Our data concerning the sensitivity related reactions show that Gorgonocephalus arcticus can evaluate the importance of a threat and has the capacity to react accordingly (Table I). This could be linked to a predation situation where the brittlestar, unable to flee rapidly (personal observations), adopts a protecting posture. This attitude could be associated with partial predation during which an animal chooses to let go of a body part instead of being totally eaten (Lawrence, 1987). In the case of ophiuroids, it is made possible by the autotomy of an arm, a procedure of energetic cost but not deadly (Jerome Clements, 1984). It would explain the covering of the disk by radii and the surrounding barrier of distal arms that could eventually be sacrificed since this organism can regenerate any ramification when the disk is intact. Detection of predators has been discussed in the studies on Ophiura ophiura by Moore and Cobb (1985a and 1986) from reactions to fast moving shadows and vibrations frequencies. These are stimuli of far perception and anticipation by the brittlestar that tends to "freeze" when detecting deep shadows or high frequency vibrations. In our experiments, the pinpoint stimulation directly on the animal's radial shield seems to induce a sense of urgency resulting in a rapid protective reaction. Sudden covering of the disk may also be related to protection against any physical disturbances besides predation, like encounter with an other organism or a sudden flow of water carrying solid particles.

A stimulation on the arms generates a less violent reaction (Table II). This agrees with the idea of partial predation mentioned above, the ramifications not being vital to ophiuroids (Lawrence, 1987), as proven by the many cases of autotomy observed among these brittlestars in a tank recreating the deep sea biota. A link with the nutrition habits could also be made. There are two major food capturing methods commonly observed among the ophiuroids : deposit feeding of small particles and carnivorous predation by means of arm-looping (Warner, 1982). The last method is used by branched euryalids or basket stars, including Gorgonocephalus arcticus, which coil their arms around prey, mainly plankters, and transfer them to the mouth (Davis, 1966; Macurda, 1976; Meyer and Lane, 1976). This feeding technique could imply that physical contact with the prey plays a role in the induction process of the capture behaviour (Warner, 1982). Macurda (1976) explains that the coiling of an arm around a prey is almost instantaneous whereas our results show often a minimum delay of $30 \mathrm{sec}$ before any reaction can be observed. It would suggest that a combined effect of mechanical and chemical stimulation is at stake in rapid prey capture. The studies of Moore (1984) and Moore and Cobb (1985b) already commented on the great sensitivity of Ophiura ophiura toward amino acids in solution. 
The work of May (1925) suggests that the closer a stimulation gets to the disk, the more global and intense will the animal's reaction be. Our results (Table II) show a clear difference in sensitivity between radial shield and arms, no matter how close to the disk a stimulation is given on the arm. Even a stimulation at the base of the arm never generates a general movement of all ramifications nor the covering of the disk, as will the stimulation of the radial shield. These differences observed in Gorgonocephalus articus compared to Ophionereis (May, 1925) could be attributed to the particular organization of the nervous system in each species. Cobb and Stubbs (1981 and 1982) rejected the idea that the circumoral nerve ring could be an integration center in Ophiura ophiura. Could such a system exist in basket stars which seem to be more developed according to the importance of their ramifications ? After studying the feeding behaviour of the basket star Astrophyton, Davis (1966) suggested a simple on/off response at the point of prey stimulation, rather than central nervous control, to explain the coordination between branches.

A complete reaction can always be observed following stimulation on the disk, even when simultaneous stimuli are applied. The disk seems to be extremely well innervated since Gorgonocephalus arcticus always covers exclusively the stimulated side of the radial shield and also locates the site of stimulation as suggested by convergence of radii on that site. The arms also seem to have this discriminatory ability up to a certain distance from the disk. A stimulus at the base or in the middle of a main ramification induces the coiling of radii around impact site, a phenomena not observed after stimulation of a far tip (Table II). Unlike the radial shield, the arms loose the ability of locating and reacting to a stimulation when two simultaneous stimuli are applied anywhere on two distinct ramifications or the same arm. However, our experiments show that two successive stimulations on the arms do not deprive the basket star of its discriminatory abilities (Table II). This suggests that food capture would be efficient only if preys are successively caught in the extended ramifications. Unless chemical stimulation constitutes the main factor in prey detection and is not altered by multiple perception. Recent neurophysiological studies on unbranched ophiuroids have investigated the alert response caused by multiple stimuli. Although mechanical stimulations may induce an activity conducted throughout the nerveus system, some will result in whole animal behaviour whereas others will affect a more localized area (Cobb, 1988 ; Cobb and Moore, 1989). G. arcticus provides a good exemple of this shift in behaviour depending on the intensity and the location of the stimulus as illustrated by the disparity between the reactions induced by a similar stimulation on the disk or on the arms (Table II).

A long stimulation seem to induce an habituation in Gorgonocephalus arcticus, showing a similarity with the habituation observed in Ophiura ophiura receiving successive mechanical stimuli (Cobb and Moore, 1989). This is also observed in higher organisms which stop reacting to a stimulus when it is prolonged (Kuffler et al., 1984).

These results give rise to a few questions. Moore and Cobb (1986) found mechanical sensory receptors located in the spines of Ophiura ophiura. But there must be other locations since reactions in Gorgonocephalus arcticus develop whether or not the stimulated area contains spines. Almost as unclear, what purpose has the persistant covering of impact area on the disk ? It seems clear that neurophysiological studies are needed to elucidate all the behaviours observed in our study, especially since great differences can be detected in the reactions of Gorgonocephalus arcticus compared to previous work on unbranched ophiuroids.

ACKNOWLEDGEMENTS - The authors greatly appreciated the assistance of Dr. J.-C. Brêthes in the collection of the basket stars. Sincere thanks also go to Dr. G. Desrosiers and Dr. E. Pelletier for critical review of the manuscript and to Johanne Noël for the Gorgonocephalus sketch.

\section{REFERENCES}

AMOS W.H. and S.H. AMOS, 1981. Atlantic and Gulf Coasts. Edited by Alfred A. Knopf, New York, 670 p.

COBB J.L.S., 1988. A preliminary hypothesis to account for the neural basis of behaviour in echinoderms. In Echinoderm Biology. Edited by Burke et al., Balkema, Rotterdam : 565-573.

COBB J.L.S. and A. MOORE, 1986. Comparative studies on receptor structure in the brittlestar Ophiura ophiura. J. Neurophysiol. 15 : 97-108.

COBB J.L.S. and A. MOORE, 1989. Studies on the integration of sensory information by the nervous system of the brittlestar Ophiura ophiura. Mar. Behav. Physiol. 14 : 211-222.

COBB J.L.S. and T.R. STUBBS, 1981. The giant neurone system I. The general morphology of the radial nerve cords and circumoral nerve ring. Cell Tissue Res. 219: 197-207.

COBB J.L.S. and T.R. STUBBS, 1982. The giant neurone system in Ophiuroids III. The detailed connections of circumoral nerve ring. Cell Tissue Res. 226 : 675-687.

COWLES R.P., 1910. Stimuli produced by light and by contact with solid walls as factors in the behavior of ophiuroids. J. Exp. Zool. 9 : 387-416. 
DAVIES W.P., 1966. Observations on the biology of the ophiuoroid Astrophyton muricatum. Bull. Mar. Sci. 16: 435-444.

DEARBORN J.H., 1977. Foods and feeding characteristics of Antarctic asteroids and ophiuroids. In Adaptations within Antarctic ecosystems. Smithsonian Inst. Publ., Washington : 293-326.

EMSON R.H. and I.C. WILKIE, 1982. The arm-coiling response of Amphipholis squamata (Delle Chiaje). In International Echinoderms Conference, Tampa Bay. Edited by J.M. Lawrence, A.A. Balkema, Rotterdam : 11-18.

FEDOTOV D.M., 1915. On the anatomy of Gorgonocephalus eucnemis (M. \& Tr.). Len. Soc. Nat. Trav. 46: 65-88.

JEROME CLEMENTS L.A., 1984. Post-autotomy feeding behavior of Micropholis gracillima (Stimpson) : Implications for regenaration. In Proceeding of the Fifth International Echinoderms Conference. Edited by B.F. Keegan and B.D.S. O'Connor, Galway : 609616.

KUFFLER S.W., J.G. NICHOLLS and A.R. MARTIN, 1984. From neuron to brain, a cellular approach to the function of the nervous system. $2^{\text {nd }}$ edition, Sinauer Associates Inc. Publishers, Sunderland, MA : 477-480.

LAWRENCE J.M., 1987. A functional biology of echinoderms. Edited by Croom Helm, Sydney, 340 p.

MACURDA D.B. Jr., 1976. Skeletal modifications related to food capture and feeding behavior of the basketstar Astrophyton. Paleobiology 2 : 1-7.

MAY R.M., 1925. Les réactions sensorielles d'une ophiure (Ophionereis reticulata), Say. Bull. Biol. France Belgique 59: 372-402.

MEYER D.L. and N.G. LANE, 1976. The feeding behaviour of some paleozoic crinoids and recent basketstars. J. Paleontol. 50 : 472-480.
MOORE A., 1984. Neurophysiological studies on the perception of environmental stimuli in Ophiura ophiura (L.) (Echinodermata, Ophiuroidea). In Proceeding of the Fifth International Echinoderms Conference. Edited by B.F. Keegan and B.D.S. O'Connor, Galway. pp. 627-631.

MOORE A. and J.L.S. COBB, 1986. Neurophysiological studies on the detection of mechanical stimuli by Ophiura ophiura (L.). J. Exp. Mar. Biol. Ecol. 104: 125-141.

MOORE A. and J.L.S. COBB, 1985a. Neurophysiological studies on photic responses in Ophiura ophiura. Comp. Biochem. Physiol. 80A : 11-16.

MOORE A. and J.L.S. COBB, 1985b. Neurophysiological studies on the detection of amino acids by Ophiura ophiura. Comp. Biochem. Physiol. 82A : 395-399.

PATENT D.H., 1969. The reproductive cycle of Gorgonocephalus caryi (Echinodermata: Ophiuroidea). Biol. Bull. 136 : 241-252.

PATENT D.H., 1970a. Life history of the basket star, Gorgonocephalus eucnemis (Müller \& Troschel) (Echinodermata : Ophiuroidea). Ophelia 8 : 145-160.

PATENT D.H., 1970b. The early embryology of the basket star Gorgonocephalus caryi (Echinodermata : Ophiuridea). Mar. Biol. 6 : 262-267.

TSURNAMAL M. and J. MARDER, 1966. Observations on the basket star Astroboa nuda (Lyman) on coral reefs at Elat (Gulf of Aqaba). Israel J. Zool. $15: 9-17$.

WARNER G., 1982. Food and feeding mechanisms : Ophiuroidea. In Echinoderm nutrition. Edited by M. Jangoux and J.M. Lawrence, A.A. Balkema, Rotterdam : 170-171.

Reçu le 3 mai 1993; received May 3, 1993 Accepté le 2 août 1993; accepted August 2, 1993 